\title{
PERBEDAAN PREFERENSI ANTARA STATED PREFERENCE DAN REVEALED PREFERENCE DEWASA MUDA TERHADAP RUMAH TINGGAL
}

\author{
Nisa Farasa \\ Program Studi Magister Arsitektur, SAPPK, Institut Teknologi Bandung \\ Kelompok Keahlian Perancangan Arsitektur, Institut Teknologi Bandung \\ Jl. B, Lb. Siliwangi, Kecamatan Coblong, Kota Bandung \\ *Email: nisafarasa@yahoo.com
}

\begin{abstract}
ABSTRAK
Rumah sebagai kebutuhan utama manusia di mana rumah juga sebagai tempat sarana pembinaan keluarga. Di dalam rumah terjadi banyak kegiatan yang juga dapat menggambarkan fungsi dari rumah. Fungsi rumah ini erat kaitannya dengan siklus hidup manusia dimana mereka memasuki fase-fase hidup mereka. Seiring dengan perkembangan jaman, fungsi rumah tinggal kini tergantung pada persepsi penghuninya. Preferensi orang terhadap hunian kini berkembang mengikuti keinginan masing- masing calon penghuni baik dari kalangan orang tua maupun dewasa muda. Begitu juga dengan yang belum memiliki rumah maupun yang sudah memiliki rumah, tentu menunjukkan preferensi yang berbeda juga. Artikel penelitian ini bertujuan mencari perbedaan antara preferensi dewasa muda jika dalam keadaan belum memiliki rumah (stated preference)dengan preferensi seseorang yang sudah pernah memiliki rumah (revealed preference). Kalangan dewasa muda akan dipilih menjadi subjek penelitian. Pengumpulan data dilakukan dengan metode survei kuesioner online yang dibagikan secara bebas (non-random sampling).Data yang terkumpul selanjutnya dianalisis secara kualitatif kemudian di cari hubungan antar kategori dengan dianalisis korespondensi. Hasil analisis mengungkapkan bahwa kategori kunci yang bersifat estetik,angan-angan dan memotivasi penghuni (seperti segi tipe desain, tipe lokasi lahan,keberadaan lingkungan alami dll) cenderung mengarah pada preferensi seseorang yang belum pernah memiliki rumah atau stated preference. Sedangkan kategori kunci yang sifatnya kebutuhan pokok, kondisi real/nyata (seperti kondisi eksternal lokasi, aksebilitas, dekat dengan fasum, kebutuhan ruang dll) cenderung mengarah pada preferensi seseorang yang sudah pernah memiliki rumah atau revealed preference.
\end{abstract}

Kata Kunci: housing preference, stated preference, reavealed preference, dewasa muda.

\section{PENDAHULUAN}

Rumah sebagai tempat tinggal adalah salah satu kebutuhan utama manusia dimana rumah juga sebagai tempat sarana pembinaan keluarga.Di dalam rumah terjadi banyak kegiatan yang dapat menggambarkan fungsi rumah yaitu sebagai fungsi sosial (tempat terjadinya hubungan interaksi sosial), fungsi ekonomi, fungsi politik, dan fungsi budaya (pola hidup penghuni). Fungsi rumah ini erat kaitannya dengan siklus hidup manusia dimana mereka memasuki fase-fase hidup mereka. Akamaru dalam Anindyajati, Soemarmo, Soemardiono (2014) mengatakan, apabila di dalam suatu keluarga memiliki anak, mereka akan lebih memilih mendahulukan kebutuhan anak di atas kebutuhannya sendiri, sehingga memilih lokasi yang berdekatan dengan fasilitas pendidikan dan kesehatan. Selain itu, mereka juga cenderung mencari hunian yang memiliki fasilitas rekreasi, perbelanjaan, dan tempat makan untuk pemenuhan kebutuhan.

Seiring dengan perkembangan jaman, fungsi rumah tinggal kini tergantung pada persepsi penghuninya. Preferensi orang terhadap hunian kini berkembang mengikuti keinginan masing- masing calon penghuni baik dari kalangan orang tua maupun dewasa muda. $\mathrm{Hal}$ ini diikuti dengan berkembangnya trend penelitian mengenai preferensi calon penghuni terhadap pemilihan rumah tinggal. Dalam penelitian yang di lakukan oleh Triyuly (2005), preferensi adalah suatu keinginan atau kecenderungan individu untuk memilih dan memiliki sesuatu. Preferensi perumahan dapat 
juga diartikan sebagai keinginan untuk memilih dan memiliki suatu kondisi atribut perumahan dengan penghuni sebagai subjek pengambil keputusan (decision making) sehingga didalamnya terkandung makna suatu proses penghuni mewujudkan kondisi rumah yang diinginkannya. Preferensi individu ini dipengaruhi oleh informasi yang berasal dari persepsi dan interaksi masyarakat dengan masyarakat lainnya berdasarkan pada latar belakang tingkat kebutuhan dan kepentingan yang berbeda (Triyuly, 2009).

Selanjutnya yang didapat pada hasil survey yang dilakukan litbang Kompas 2012 menyatakan bahwa status kepemilikan rumah di 12 kota besar di Indonesia mayoritas dihuni oleh keluarga muda yaitu sebesar 27,5\%. (Anindyajati et.al.,2014). Hal ini menunjukkan bahwa keluarga muda, baik dengan status belum menikah maupun di usia pernikahan yang masih tergolong dini, sudah berpikiran kedepan untuk memiliki rumah tinggal sendiri sebagai pemenuhan kebutuhan hidup sebuah keluarga. Hal inilah yang menyebabkan responden dewasa muda dijadikan subjek pada penelitian ini.

Diduga preferensi bagi dewasa muda yang belum memiliki rumah (dalam artikel disebut stated preference) maupun yang sudah memiliki rumah (pada artikel revealed preference) tentu menunjukkan preferensi yang berbeda juga. Penamaan pada artikel ini mengacu pada Willingness to Pay (WTP) (Anderson, 1993) di mana Stated Preference ditujukan kepada responden yang tidak berada pada kondisi yang dinyatakan. Sedangkan Revealed Preference lebih mendekati pada daya guna yang dirasakan oleh responden. Pada Revealed Preference memiliki pengertian yang sesuai dengan perilaku nyata, tetapi data pada Stated Preference mungkin berbeda dengan perilaku nyatanya.

Dari penjelasan di atas, maka artikel penelitian ini bertujuan mencari perbedaan antara preferensi dewasa muda dalam memilih rumah tinggal, jika dalam keadaan belum memiliki rumah, rumah seperti apa yang akan di pilihnya sebagai tempat tinggal dan dengan preferensi seseorang yang sudah pernah memiliki rumah. Sehingga dicari bagaimana preferensi dewasa muda dalam memilih rumah tinggal, baik bagi yang belum pernah memiliki rumah tinggal maupun yang sudah pernah memiliki rumah tinggal sendiri. Lalu bagaimana hasil yang di dapat dari perbedaan preferensi antara jawaban responden yang belum pernah mempunyai rumah tinggal sendiri dengan yang sudah memiliki rumah tinggal. Dikarenakan fase hidup dewasa muda adalah fase awal bagi seseorang dalam menentukan pilhan hidup, salah satunya rumah tinggal maka kalangan dewasa muda akan dipilih menjadi subjek penelitian dalam artikel ini.

\section{METODE PENELITIAN}

Penelitian ini bertujuan untuk mencari perbedaan antara preferensi dewasa muda dalam memiliki rumah tinggal dari sudut pandang dewasa muda jika dalam keadaan belum memiliki rumah dengan preferensi seseorang yang sudah pernah memiliki rumah. Pendekatan penelitian ini adalah pendekatan kualitatif deskriptif (Creswell, 2002).Subjek penelitian adalah dewasa muda yang berumur 22-33 tahun baik yang belum pernah mempunyai rumah sendiri maupun mereka yang sudah pernah menempati rumah sendiri.

Metode Pengumpulan data dilakukan dengan pendekatan Grounded Theory (Creswell, 1998).Pengumpulan data dilakukan dengan cara metode survei kuesioner online yang dibagikan secara bebas (non-random sampling)yang berisikan pertanyaan terbuka. Hal ini dilakukan dengan pertimbangan bahwa yang akan menjadi responden adalah kalangan dewasa muda di mana mereka mampu untu mengakses internet sehingga diharapkan jawaban yang diberikan dapat lebih baik dan jelas. Data yang terkumpul selanjutnya dianalisis secara kualitatif kemudian di cari hubungan antar kategori dengan dianalisis korespondensi.

Metode analisis data yang digunakan adalah content analysis atau analisis isi yang bertujuan mengetahui semua jawaban yang diberikan responden terkait dengan preferensi mereka masing-masing terhadap hunian. Jawaban dari responden diharapakan akan berbeda-beda sesuai dengan karakteristik dan kebutuhan penghuni baik yang belum memiliki rumah maupun yang sudah memiliki. Kemudian dilakukan tiga tahapan yaitu open coding, axial coding, dan selective coding (Creswelll, 1998) yang dapat dijelaskan sebagai berikut.

1. Tahap open coding, merupakan tahapan identifikasi kata kunci dari jawaban responden. Jawaban ini berupa data text yang diberikan oleh responden terkait dengan preferensi rumah. 
2. Tahap axial coding, yaitu dengan membuat kategori-kategori dari kata kunci yang sudah didapatkan dari tahap sebelumnya.

3. Tahap selective coding, yaitu membuat hubungan antar kategori dan hasil perhitungan frekuensi. Hubungan antar kategori dilakukan dengan distribusi frekuensi dan analisis korespondensi.

\section{HASIL DAN PEMBAHASAN}

Responden yang terdiri dari 181 orang dengan laki-laki sebanyak 81 orang $(45,4 \%)$ dan perempuan sebanyak 99 orang $(54,6 \%)$ (Gambar $1)$.

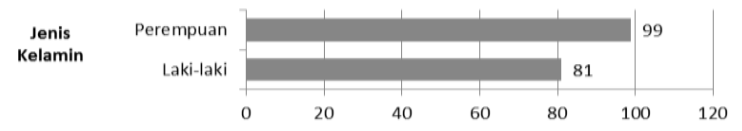

Gambar 1. Diagram Jumlah Jenis Kelamin Responden

Selain itu 147 responden $(81,2 \%)$ terdata belum memiliki rumah sendiri, dan sisanya sebanyak 33 responden $(18,8 \%)$ telah memiliki rumah sendiri. Banyaknya responden yang belum memiliki rumah dimungkinkan karena status mereka yang juga belum menikah. Sehingga diduga banyak dari mereka masih menyewa(kos) atau mengontrak rumah di kota tempat responden bekerja (Gambar 2).

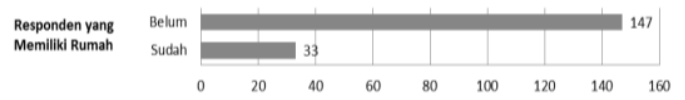

Gambar 2. Diagram Jumlah Responden yang Memiliki Rumah Tinggal Sendiri

Dengan melihat dugaan perbedaan preferensi akibat kebutuhan masing-masing responden maka dibutuhkan status responden yaitu status responden dengan jumlah 133 respondene $(73,5 \%)$ adalah responden yang belum menikah, 23 responden $(12,7 \%)$ menikah belum mempunyai anak, dan 24 responden $(13,8 \%)$ sudah menikah dan memiliki anak. Kemungkinan didapat banyaknya hasil yang belum menikah karena adanya batasan umur yang di ambil untuk umur dewasa muda, yaitu umur 22tahun-33tahun. Selain itu di Indonesia ada kecenderungan bahwa umur-umur dewasa muda khususnya setelah lulus kuliah, dewasa muda berfokus pada mengejar cita-cita dalam hal karir, sehingga membentuk keluarga kecil dan mencari pendamping hidup setelah karir dirasa stabil dan mapan (Gambar 3).

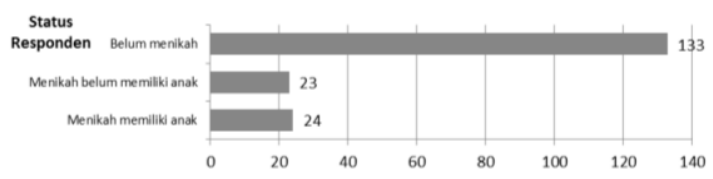

Gambar 3. Diagram Jumlah Status Responden

Sedangkan untuk pendapat tertinggi dari responden sebanyak 62 responden atau 34,2\% berpenghasilan $\quad 0-\mathrm{Rp} \quad 2.000 .000$, kemudian diikuti dengan berpenghasilan $\mathrm{Rp}$ 4.000.000-Rp 8.000 .000 sebanyak $26,5 \%$ atau sebanyak 48 responden, $24,8 \%$ atau sebanyak 45 responden berpenghasilan $\mathrm{Rp} \quad 2.000 .000-\mathrm{Rp} \quad 4.000 .000$, $11 \% \quad$ (20 responden) berpenghasilan $\mathrm{Rp}$ 8.000.000-Rp 16.000.000, Sisanya 2,2\% (4 responden) berpenghasilan melebihi $\mathrm{Rp}$ 32.000 .000 dan hanya 1 responden $(0,5 \%)$ berpenghasilan $\mathrm{Rp} \quad 16.000 .000$. Banyaknya penghasilan dari 0 hingga $\mathrm{Rp} \quad 8.000 .000$ dimungkinkan karena jenjang karir dari dewasa muda yang baru mulai menapaki dunia pekerjaan. Sehingga beberapa sedang berada pada tingkat awal, dan sebagian juga tidak jarang yang masih sekedar coba-coba (Gambar 4).

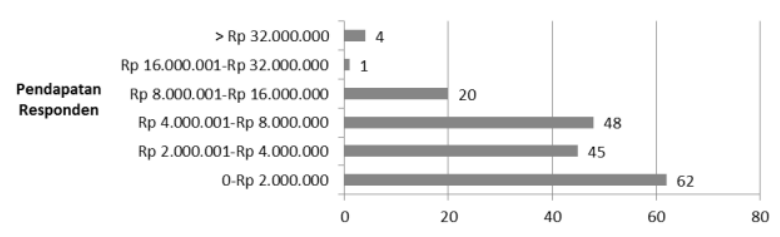

Gambar 4. Diagram Penghasilan Responden

Berdasarkan dari hasil analisis open coding, diketahui bahwa dari 77 kata kunci dengan total frekuensi sebanyak 450 dan yang teridentifikasi dikategorikan menjadi 14 kategori.Selanjutnya, berdasarkan berdasarkan hasil identifikasi kata kunci yang dilakukan, kemudian dilakukan pengkategorian kata kunci yang disebut dengan tahapan analisis axial coding. Perlu diadakan diskusi kelompok dengan metode workshop untuk menghindari terjadinya bias.

Banyaknya kata kunci yang sering muncul terdapat pada kategori adanya keberadaan lingkungan alami (69) pada pemilihan rumah tinggal. Kata kunci yang mewakili seperti terdapat halaman, taman, ada banyak pohon/tanaman, terdapat kolam ikan, dan ada saung atau gazebo pada area taman. (Tabel 1). 
Kemudian diikuti kategori kebutuhan ruang dengan frekuensi sebanyak 67. Kebutuhan ruang disini adalah apa saja ruangan yang di butuhkan oleh responden seperti adanya ruang tamu, ruang keluarga, dapur, ruang makan, kamar mandi, kamar tidur, garasi/carport, ruangan kerja, teras, dan are menjemur (Tabel $1)$.

Dekat dengan Fasum juga menjadi bahan pertimbangan dengan frekuensi sebanyak 59 preferensi rumah tinggal. Kata kunci dari kategori ini adalah dekat dengan tempat kerja, tempat ibadah, sekolah, fasilitas kesehatan, dan pasar. Penelitian lain menemukan bahwa masyarakat berkembang memilih tempat tinggal karena kedekatan geografis untuk memenuhi kebutuhan sehari-hari (toko-toko, restoran, tempat kerja, sekolah, transportasi umum dan ruang), dan kenyamanan yang diberikan (Haarhoff et al., 2012; Syme, McGregor dan Mead, 2005) (Tabel 1).

Tabel 1. Tabel frekuansi kategori

\begin{tabular}{lr}
\hline \multicolumn{2}{c}{ Preferensi Rumah Tinggal } \\
\hline Lokasi Strategis & 18 \\
Dekat dengan Fasum & 59 \\
Dekat dengan Keluarga Besar & 2 \\
Aksebilitas & 28 \\
Tipe Lokasi Lahan & 14 \\
& \\
Tipe Rumah & 28 \\
Desain Rumah & 39 \\
Kebutuhan Ruang & 67 \\
Sarana Pra-sarana & 21 \\
Keberadaan Lingkungan Alami & 69 \\
Kualitas Ruang & 34 \\
Kelapangan Ruangan & 11 \\
Kondisi Eksternal Lokasi & 13 \\
Accepting My Portion in Life & 47 \\
\hline
\end{tabular}

Selanjutnya adalah tahapan selective coding di mana perlu diketahui bagaiaman hubungan antar kategori kata kunci yang didapatkan dari analisis sebelumnya dengan melakukan analisis korespondensi antara preferensi pemilihan rumah tinggal bagi yang sudah memiliki rumah (revealed preference) dengan yang belum pernah memiliki rumah tinggal (stated preference)

Berdasarkan analisis tersebut, maka diketahui bahwa kategori kata kunci adanya sarana pra-sarana sangat dekat dengat preferensi responden yang belum memiliki rumah (stated preference). Kata kunci yang mewakili adalah tersedianya air bersih, terdapat sarana pra sarana yang memadai, tersedia listrik, drainase yang baik, dan memiliki panel surya (lihat pada diagram 1). Seperti yang diungkap oleh Anindyajati et al (2014) bahwa hasil variabel yang paling berpengaruh adalah infrastruktur dan utilitas umum yaitu ketersediaan air bersih, ketersediaan jaringan listrik, adanya sistem pembuangan limbah dan sampah, kualitas material bangunan, dan sistem drainase yang baik.

Selain itu beberapa kategori lain yang dekat dengan stated preference adalah kelapangan ruangan (yaitu luas/lebarnya ruangan dan tidak banyak sekat), accepting my portion in life yang berisi dengan tidak ingin memiliki rumah yang berlebihan di wakili dengan kata kunci tidak ingin rumah terlalu lebar, rumah sederhana, tidak rumit/ simpel, yang sedang-sedang saja, yang penting layak huni, dan seadanya. Kemudian diikuti dengan adanya lingkungan alami, kualitas ruangan (memiliki sirkulasi udara yang baik, pencahayaan baik, terdesain dengan baik, orientasi jendela, interior yang baik, dan efesiensi ruangan), tipe rumah (rumah landed, apartement, rumah bertingkat, rumah landed), lokasi strategis, desain rumah (minimalis, klasik, arsitektur tropis, traditional modern, dll), dan terakhir tipe lokasi lahan seperti lahan dekat dengan pusat kota, jauh dari keramaian, di perbukitan, atau berada di tengah kota. Menurut Surowiyono dan Tutu (2007). Dua hal penting yang perlu diperhatikan sebagai dasar pertimbangan lokasi adalah kondisi lingkungan secara geografis dan kondisi lingkungan menurut kebutuhan strategis (Diagram 1).

Sedangkan pada revealed preference hanya ada 4 kategori yaitu kondisi ekstenal lokasi (bukan kawasan banjir, bebas macet, kondisi jalan baik), aksebilitas (terkait dengan akses yang mudah dan murah dijangkau), dan dekat dengan rumah keluarga besar. Pernyataan lokasi dekat dengan keluarga besar jarang terungkap pada jurnal lain maka dari itu kategori ini tidak penulis gabungkan dengan kategori lain karena diduga keluarga besar masih berperan kuat dalam pemilihan rumah tinggal pada dewasa muda. Levy dan Lee (2004) mempelajari dampak dari anggota keluarga terhadap keputusan pembelian rumah tinggal melalui analisis pengalaman agen real estate. Mereka berpendapat bahwa proses pembelian rumah merupakan proses kegiatan inheren, 
meliputi penetapan tujuan, diskusi dan negosiasi mengenai kebutuhan keluarga dan apa yang keluarga inginkan, terlibat dengan perantara perumahan, memiliki inovasi untuk merenovansi segala hal yang memiliki potensial, serta menyimpulkan tren yang terjadi di pasar (Levy et al., 2008). struktur keluarga, etnis, peran gender dan status sosial-ekonomi semua memainkan peran berpengaruh dalam membentuk kegiatan ini.

Visualisasi dari hasil analisis korespondensi kemudian digambarkan dengan diagram bubble dengan diameter dari masingmasing lingkaran merepresentasikan frekuensi kategori kata kunci serta kedekatan lingkaran menggambarkan hubungan korespondensi terdekat antar kategori kata kunci yang ada (Gambar 5).
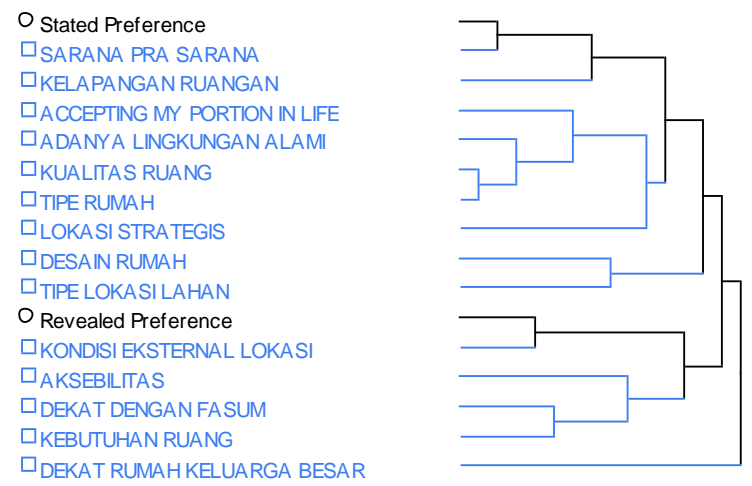

Gambar 5. Dendogram Hubungan Kategori Kata

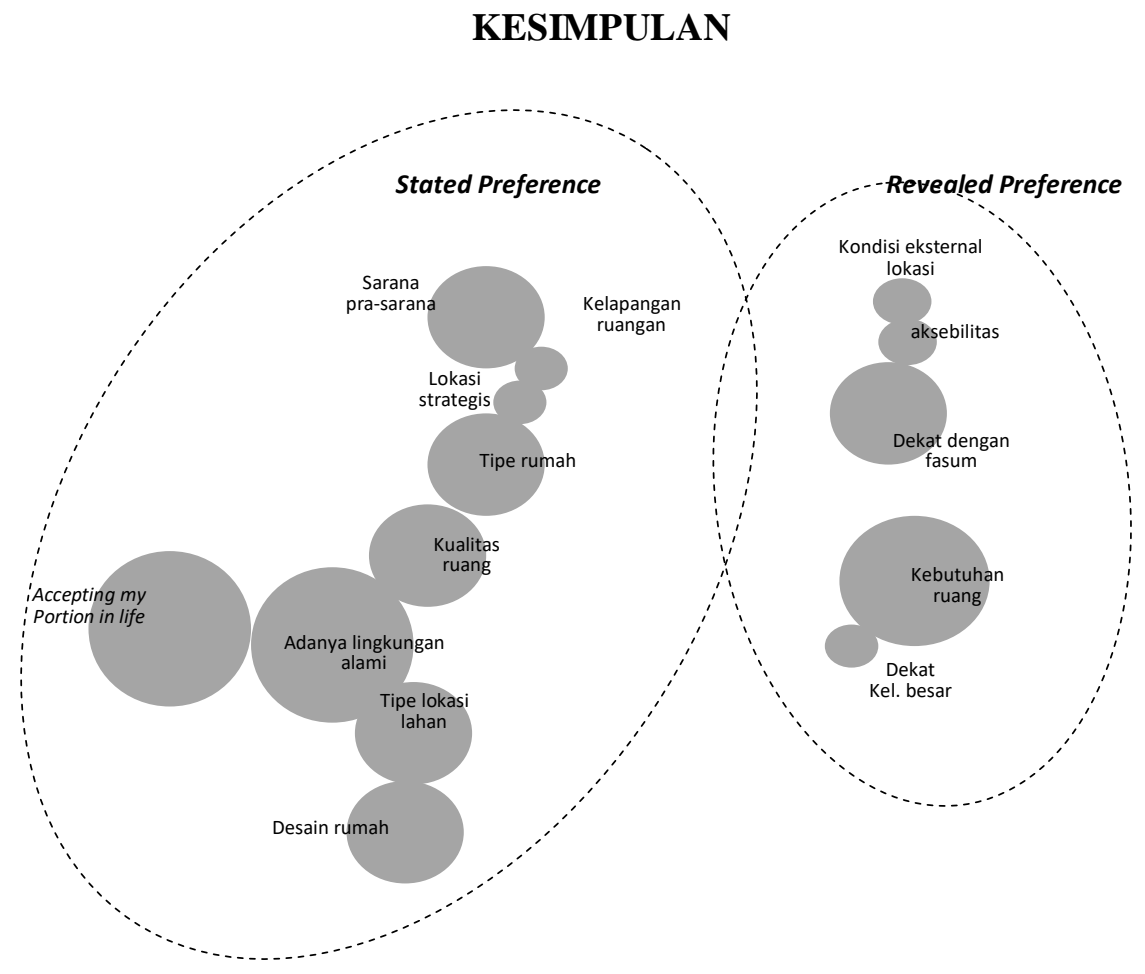

Gambar 6. Diagram Bubble Kategori

Jika mengacu pada Gambar 6 menunjukkan bahwa kategori kunci yang bersifat estetik, angan-angan dan memotivasi penghuni (seperti segi tipe desain, tipe lokasi lahan, keberadaan lingkungan alami dll) cenderung mengarah pada preferensi seseorang yang belum pernah memiliki rumah (Stated Preference). Sedangkan kategori kunci yang sifatnya kebutuhan pokok, kondisi real/nyata (seperti kondisi eksternal lokasi, aksebilitas, dekat dengan fasum, kebutuhan ruang dll) cenderung mengarah pada preferensi seseorang yang sudah pernah memiliki rumah (Revealed Preference). Menurut Mulder (1996) dan Timmermans, Molin, dan Van Noortwijk (1994) revealed preference berfokus pada hasil dari proses pilihan tersebut, sementara stated preference lebih memperhatikan pada preferensi pribadi seseorang terhadap rumah yang akan ditinggal, keinginan dan aspirasi. 


\section{Daftar Pustaka}

Anindyajati, D. J., Soemarmor, I., dan Soemardiono, B. (2014) Preferensi Keluarga Muda Dalam Memilih Rumah Tingagal di Surabaya Berdasarkan Atribut Fisik dan Infrastruktur Perumahan. Prosiding Seminar Nasional Manajemen Teknologi XX ISBN :978-602-97491-9-9.

Anderson, James C., Dipak Jain, and Pradeep K. Chintagunta. (1993) Understanding Customer Value in Business Markets: Methods of Customer Value Assessment. Journal of Business to Business Marketing. 1 (1), 3-30.

Cresswell, J. W. (1998) Qualitative Inquiry and ResearchDesign Choosing. Among Five Traditions. California: Sage Publications.

Creswell, J. W. (2002) Research Design: Qualitative, Quantitative, and Mixed Methods Approaches. Second edition. Sage Publications: International Education and Professional Pubisher.

Haarhoff, E., Beattie, L., Dixon, J., Dupuis, A., Lysnar, P and Murphy, L. (2012) Future intensive: Insights for Auckland's housing: A research report prepared for the Auckland Council. Transforming Cities: Innovations for Sustainable Futures: The University of Auckland.

Levy, D and Lee, C. (2004) The influence of family members on housing purchase decisions. Journal of Property Investment and Finance, 22(4), 320338.

Levy, D., Murphy, L and Lee, C. (2008) Influences and emotions: exploring family decision-making processes when buying a house. Housing Studies, 23(2), 271-289.

Mulder. (1996) Housing choice: Assumptions and approaches. Netherlands Journal of Housing and the Built Environment, 11(3), 209-232.
Surowiyono, Tutu T.W. (2007) Dasar Perencanaan Rumah Tinggal. Jakarta: Sinar Harapan.

Syme, C., McGregor, V and Mead, D. (2005) Social implications of housing intensification in the Auckland region: Analysis and review of media reports, surveys and literature. Unpublished report, part of Auckland Sustainable Cities Programme (Urban Form, Design and Development work strand).

Timmermans, H., Molin, E and van Noortwijk, L. (1994) Housing choice processes: Stated versus revealed modelling approaches. Journal of Housing and the Built Environment, 9(3), 215-227.

Triyuly, Wienty. (2005) Kebutuhan Perumahan Untuk Keluarga Muda Berdasarkan Perspektif Perkembangan Keluarga di Kota Palembang. Bandung: ArsitekturITB.

Triyuly, Wienty. (2009) Model Perumahan Bagi Masyarakat Berpenghasilan Rendah Di Kota Palembang Berdasarkan Preferensi Dan Tingkat Keterjangkauan (Affordability) Masyarakat. Palembang: Arsitektur-Unsri. 